Historia: Jurnal Program Studi Pendidikan Sejarah

Vol. 3 No. 2 (2018): 77-91

P-ISSN 2301-8305

E- ISSN 2599-0063

\title{
UPAYA MENINGKATKAN MINAT BELAJAR SISWA PADA MATA PELAJARAN IPS TERPADU MELALUI METODE KARYAWISATA KELAS VIIC SMPN 50 BATAM
}

\section{EFFORTS TO IMPROVE STUDENTS INTEREST IN INTEGRATED IPS SUBJECTS THROUGH LEISURE CLASS METHOD VIIC SMPN 50 BATAM}

\author{
Desma Yulia ${ }^{1}$, Rezky Mulia ${ }^{2}$ \\ ${ }^{1}$ (Program Studi Pendidikan Sejarah, FKIP Universitas Riau Kepulauan, Indonesia) \\ 2 (Program Studi Pendidikan Sejarah, FKIP Universitas Riau Kepulauan, Indonesia) \\ ${ }^{1}$ Desmayulia45@gmail.com, ${ }^{2}$ rezkymulia@gmail.com
}

\begin{abstract}
Abstrak
Pemakaian metode ceramah yang digunakan oleh guru dalam menyampaikan materi pembelajaran membuat siswa kurang merasa senang dan bersemangat dalam pembelajaran. Hal tersebut terlihat dari minat belajar siswa yang kurang terhadap mata pelajaran IPS Terpadu siswa kelas VIIC SMP Negeri 50 Batam. Penelitian ini bertujuan untuk mengetahui apakah metode karyawisata dapat meningkatkan minat belajar siswa IPS Terpadu di kelas VIIC SMP Negeri 50 Batam tahun pelajaran 2015/2016.Jenis penelitian ini adalah penelitian tindakan kelas (PTK) dengan desain penelitian model Kemmis dan MC Tagart. Siswa yang diteliti yaitu kelas VIIC SMP Negeri 50 Batam menggunakan dua siklus. Satu siklus terdiri dari empat langkah, yaitu perencanaan (planning), aksi atau tindakan (acting), observasi (observing), dan refleksi (reflecting). Teknik analisa data menggunakan angket dalam setiap tindakan, angket dibagian setelah diterapkannya metode pembelajaran dikelas. Hasil penelitian ini menunjukkan bahwa terdapat perbedaan yang signifikan terhadap minat belajar siswa pada kelas VIIC SMP Negeri 50 Batam sebelum dan sesudah memakai metode karyawisata. Hal ini ditunjukkan dengan peningkatan persentase minat belajar siswa dari perencanaan, pelaksanaan, pengamatan, dan refleksi berdasarkan jumlah rata-rata peresentase minat siswa yang diambil dari angket. Pada pra tindakan siswa yang berminat 49,95 $\%$, siklus I siswa yang berminat sebanyak 74,933\%, sedangkan pada siklus II siswa yang berminat meningkat menjadi 81,967\%. Untuk tingkat minat belajar pada penelitian ini sudah dapat dikatakan berhasil karena $\geq 75 \%$ dari jumlah seluruh siswa sudah mencapai kriteria keberhasilan yang ditentukan.
\end{abstract}

Kata kunci: Metode Karyawisata, IPS Terpadu, Minat Belajar Siswa

\begin{abstract}
This study aims to determine whether a field method can increase student interest in the class VIIC Integrated IPS SMP Negeri 50 Batam in the academic year 2015/2016. This research is a classroom action research (PTK) with the study design and MC Tagart Kemmis models. students studied were class VIIC SMP Negeri 50 Batam using two cycles. One cycle consists of four steps: planning (planning), action or action (acting), observation (observing) and reflection (reflecting). Data analysis technique using questionnaires in any action, the questionnaire section after the implementation of teaching methods in class.The results of this study indicate that there are significant differences on the interest of students in a class VIIC SMP Negeri 50 Batam before and after using a field method. This is indicated by the percentage increase student interest of planning, implementation, observation, and reflection based on the average number peresentase interest of students drawn from the questionnaire. In the pre-action by the students who 49.95\%, the first cycle of students who are interested in as much as $74.933 \%$, while in the second cycle students who has increased to $81.967 \%$. For the level of interest in learning on this research has been relatively successful for $\geq 75 \%$ of the total number of students already achieving the success criteria specified.
\end{abstract}

Keywords: Method of Fielil Trip, IPS Terpadu, Student Learning Interests 
Historia: Jurnal Program Studi Pendidikan Sejarah

Vol. 3 No. 2 (2018): 77-91

P-ISSN 2301-8305

E- ISSN 2599-0063

\section{PENDAHULUAN}

Pendidikan merupakan kebutuhan yang sangat penting guna membangun manusia yang berpengetahuan, bermoral, dan bermartabat tanpa pendidikan manusia menjadi terbelakang dan sulit berkembang. Pendidikan merupakan investasi yang paling utama bagi setiap bangsa terlebih bagi bangsa yang sedang berkembang dan yang sedang membangun Negaranya. Menurut Undang-Undang Nomor 20 Tahun 2003 tentang Sistem Pendidikan Nasional, pendidikan adalah usaha sadar dan terencana untuk mewujudkan suasana belajar dan proses pembelajaran agar peserta didik secara aktif mengembangkan potensi dirinya untuk memiliki kekuatan keagamaan, pengendalian diri, kepribadian, kecerdasan, akhlak mulia, keterampilan yang diperlukan dirinya, masyarakat, bangsa, dan Negara. Pengertian Pendidikan yang benar menurut William Butler Yeats (Sutikno, $2014:$ 3) yaitu pendidikan yang benar adalah yang bisa memanfaatkan bekal si anak ini dengan baik sehingga semakin berkembang maksimal, seperti api yang dinyalakan kembali (Sutikno, 2014: 3).

Ada beberapa indikator siswa yang memiliki minat belajar menurut Sukartini (Karwati, 2014: 150) yaitu: a) Keinginan untuk mengetahui/memiliki sesuatu; b) Obyek-obyek atau kegiatan yang disenangi; c) Jenis kegiatan untuk memperoleh sesuatu yang disenangi; dan d) Upaya-upaya yang dilakukan untuk merealisasikan keinginan/rasa senang terhadap obyek atau kegiatan tertentu. Berdasarkan informasi dari guru bidang studi IPS Terpadu dan observasi peneliti pada saat Pelaksanaan Program Pengalaman Lapangan (PPL) di kelas VII C SMP Negeri 50 Batam bahwa minat belajar siswa masih rendah. Penelitian ini diharapkan mampu meningkatkan minat belajar IPS Terpadu. Kurangnya minat belajar siswa pada mata pelajaran IPS Terpadu di sekolah karena guru bidang studi yang masih memakai metode ceramah. Kesimpulan ini diambil penulis berdasarkan dari hasil Program Pengalaman Lapangan (PPL) pada bulan Agustus sampai Desember 2015.

metode karyawisata dengan kata lain peserta didik masih asing dengan adanya metode karyawisata di sekolah.

Peneliti menggunakan metode karyawisata untuk melihat apakah ada peningkatkan minat belajar peserta didik dalam mata pelajaran IPS Terpadu melalui metode karyawisata. Minat 
Historia: Jurnal Program Studi Pendidikan Sejarah

Vol. 3 No. 2 (2018): 77-91

P-ISSN 2301-8305

E- ISSN 2599-0063

siswa yang masih kurang dalam pembelajaran IPS Terpadu membuat penulis tertarik melakukan penelitian dengan judul: "upaya meningkatkan minat belajar siswa pada mata pelajaran IPS Terpadu melalui metode karyawisata di kelas VII C SMP Negeri 50 Batam tahun pelajaran 2015/2016”.

Menurut Moh. Surya pengertian belajar (Susanti, 2011: 1), menyatakan bahwa belajar dapat diartikan sebagai suatu proses yang dilakukan oleh individu untuk memperoleh perubahan prilaku baru secara keseluruhan, sebagai hasil dari pengalaman individu itu sendiri dalam berintraksi dalam lingkungannya. Witherington (Susanti, 2011: 1) belajar merupakan perubahan dalam kepribadian yang dimanifestasikan sebagai pola-pola respons yang baru berbentuk keterampilan, sikap, kebiasaan, pengetahuan dan kecakapan. Terkait dengan ini, proses belajar dan perubahan dalam kepribadian seseorang merupakan bentuk baru dari proses belajar. Belajar tidak hanya mempelajari mata pelajaran tetapi juga penyusunan, kebiasaan, persepsi, kesenangan, atau minat, penyesuaian sosial, bermacam-macam keterampilan lain, dan cita-cita. Seseorang dikatakan belajar apabila terjadi perubahan dari dirinya ke arah yang lebih baik dan maju dengan adanya latihan dan pengalaman dari interaksi dengan lingkungan sekitar.

\section{METODOLOGI}

Suatu penelitian dikatakan sebagai PTK partisipan ialah apabila orang yang akan melakukan penelitian harus terlibat langsung di dalam proses penelitian sejak awal sampai dengan hasil penelitian berupa laporan. Peneliti membaur dengan subjek penelitiannya dengan demikian, sejak perencanaan penelitian peneliti memantau, mencatat, dan mengumpulkan data, lalu menganalisis data serta berakhir dengan melaporkan hasil penelitiannya (Paizaluddin, 2014: 28).

Penulis melakukan penelitian tindakan kelas ini di kelas VII C SMP N 50 Batam beralamat di Tunas Regency Kelurahan Sei Binti Kecamatan Sagulung Batam dengan jumlah siswa yang menjadi subjek penelitian adalah 40 orang, terdiri dari 21 orang siswa laki-laki dan 19 orang siswa perempuan. Alasan pemilihan lokasi penelitian di SMP N 50 Batam karena minat belajar siswa IPS Terpadu menurun di SMP Negeri 50 Batam sehingga peneliti tertarik untuk melakukan penelitian di SMP Negeri 50 Batam. 
Historia: Jurnal Program Studi Pendidikan Sejarah

Vol. 3 No. 2 (2018): 77-91

P-ISSN 2301-8305

E- ISSN 2599-0063

\begin{tabular}{|c|c|c|c|}
\hline Kelas & $\begin{array}{c}\text { Jumlah } \\
\text { Siswa }\end{array}$ & $\begin{array}{c}\text { Jumlah } \\
\text { Siswi }\end{array}$ & Total Keseluruhan \\
\hline VII A & 23 & 15 & 38 \\
\hline VII B & 19 & 20 & 39 \\
\hline VII C & 21 & 19 & 40 \\
\hline VII D & 20 & 18 & 39 \\
\hline VII E & 16 & 22 & 39 \\
\hline VII F & 18 & 20 & 38 \\
\hline \multicolumn{2}{|c|}{$\begin{array}{c}\text { Jumlah siswa } \\
\text { keseluruhan }\end{array}$} & $\mathbf{2 3 3}$ siswa \\
\hline
\end{tabular}

Guru harus dapat mengumpulkan data selama melaksanakan PTK. Data itu dapat diambil melalui berbagai cara untuk mengetahui jenis data yang diteliti. Jenis data yang akan dikumpulkan dan akan digunakan sebagai dasar untuk menilai keberhasilan atau ketidakberhasilan tindakan perbaikan pembelajaran yang dicobakan, dapat bersifat kualitatif, kuantitatif atau kombinasi keduanya. Jenis alat pengumpulan data yang diperlukan dalam PTK harus diuraikan dengan jelas, seperti melalui pengamatan partisipatif, pembuatan interaksi dalam kelas (analisis sosiometrik), pengukuran hasil belajar dengan berbagai prosedur assemen (penilaian) dan sebagainya Widyatama (Paizaluddin, 2014: 112).

Instrumen yang digunakan dalam penelitian ini adalah:

a. Lembar observasi

b. Pedoman wawancara

c. Angket

Data yang diperoleh peneliti ini adalah sebuah informasi yang berkaitan dengan keberhasilan siswa dalam meningkatkan minat belajar dengan menggunakan metode karyawisata. Data yang diperoleh meliputi data sekolah, data siswa, dan data hasil belajar siswa. Data diperoleh dari beberapa sumber yaitu: 
Historia: Jurnal Program Studi Pendidikan Sejarah

Vol. 3 No. 2 (2018): 77-91

P-ISSN 2301-8305

E- ISSN 2599-0063

a. Informasi perihal kondisi siswa serta proses pembelajaran sebelum dilakukan penelitian tindakan kelas diperoleh dari guru mata pelajaran IPS Terpadu yang sebagai guru mitra peneliti.

b. Siswa kelas VIII C sebagai subyek penelitian berupa nilai tes atau minat belajar siswa terhadap mata pelajaran IPS Terpadu setelah diterapkan metode karyawisata.

c. Guru, untuk melihat tingkat keberhasilan implementasi pembelajaran metode Karyawisata dan minat belajar serta aktivitas siswa dalam proses belajar.

d. Hasil angket dan wawancara dengan guru bidang studi mata pelajaran IPS Terpadu dari siswa kelas VII C untuk mengetahui perasaan dan minat siswa terhadap pelajaran IPS Terpadu setelah melakukan metode Karyawisata.

Lembar angket minat harus sudah dibuat sebelum PTK dimulai. Angket dapat dibuat sendiri, mengadopsi, atau mengadaptasi, tetapi yang jelas setiap angket dibuat berdasarkan jabaran aspek yang akan diteliti yang diambil dari teori. Pemberian skor untuk lembar angket minat belajar siswa menggunakan pernyataan siswa yang terdiri dari sangat setuju, setuju, raguragu, tidak setuju, sangat tidak setuju. Angket yang digunakan adalah angket tertutup, yaitu angket yang sudah disediakan jawabannya sehingga tugas siswa hanya memilih jawaban yang menurutnya sesuai. Angket berisi 30 pernyataan alternatif jawaban yang digunakan dalam angket ini ada 5, yaitu SS, S, R, TS dan STS. Kriteria skor angkrt minat belajar siswa menggunakan skala likert untuk mengukur sikap, pendapat, dan persepsi seseorang atau sekelompok orang, dengan kriteria pemberian skor sebagai berikut:

Kriteria Skor Angket Minat

\begin{tabular}{|c|c|c|}
\hline \multicolumn{3}{|c|}{ Pertanyaan } \\
\hline Opsi & Nilai Skor positif (+) & Nilai Skor Negatif (-) \\
\hline SS & 5 & 1 \\
\hline S & 4 & 2 \\
\hline R & 3 & 3 \\
\hline TS & 2 & 4 \\
\hline STS & 1 & 5 \\
\hline
\end{tabular}


Historia: Jurnal Program Studi Pendidikan Sejarah

Vol. 3 No. 2 (2018): 77-91

P-ISSN 2301-8305

E- ISSN 2599-0063

Berdasarkan jumlah pernyataan dan skor yang ditentukan maka skor maksimal yang akan dicapai siswa yaitu 150 dan skor minimal yaitu 30. Data yang diperoleh kemudian dihitung, setelah itu dipersentase dengan demikian dapat diketahui bahwa peningkatan minat belajar dan pemecahan masalah siswa dalam proses pembelajaran IPS Terpadu melalui indikator keberhasilan yang disajikan secara deskriptif. Persentase perolehan skor pada lembar angket minat dikelompokkan sesuai dengan kriteria untuk menentukan tingkat minat belajar siswa. Menurut Peratiwi (2013: 83) pengukuran minat secara klasikal didasarkan pada rata-rata skor yang diperoleh siswa, kemudian diambil kesimpulan sesuai kriteria dengan menggunakan rumus berikut ini.

\section{PEMBAHASAN}

\section{Perencanaan tindakan I}

Rencana pembelajaran siklus I difokuskan untuk mengatasi masalah yang ditemukan pada observasi awal dan pra siklus dengan menggunakan metode karyawisata dan di dampingi metode ceramah. Rencana pelaksanaan tindakan dilaksanakan pada hari jumat setelah peneliti memperkenalkan diri dan menjelaskan maksud kedatangan peneliti di kelas VIIC. Pembelajaran akan dilaksanakan dengan metode karyawisata dengan materi pengertian lembaga dan jenis lembaga. Selama proses pembelajaran berlangsung, peneliti bertindak sebagai guru bidang studi sedangkan guru mitra bertindak sebagai observer yang mengamati segala kegiatan selama proses pembelajaran berlangsung.

\section{Pelaksanaan tindakan I}

Pada hari jumat 27 Mei 2016 pada jam 13.30-14.30 WIB, guru mitra mengajak peneliti masuk untuk memberitahukan maksud dan tujuan peneliti datang di SMP Negeri 50 Batam, khususnya di kelas VIIC. Guru memberikan kesempatan pada peneliti untuk memperkenalkan diri, menjelaskan maksud dan tujuan penelitian dilakukan di kelas VIIC. Siswa-siswi kelas VIIC menyambut peneliti dengan senang hati dan siap menjalani kerja sama dalam meningkatkan minat belajar siswa dengan metode karyawisata. 
Historia: Jurnal Program Studi Pendidikan Sejarah

Vol. 3 No. 2 (2018): 77-91

P-ISSN 2301-8305

E- ISSN 2599-0063

\section{Tahapan pengamatan Siklus I}

Tahapan pengamatan siklus I dilakukan untuk mengetahui setiap kegiatan dalam pelaksanaan dengan mengunakan metode karyawisata. Tahap pengamatan dilakukan bersamaan dengan pelaksanaan tindakan.

\section{Refleksi I}

Berdasarkan hasil pengamatan yang dilakukan pada siklus I dapat dilihat bahwa penerapan metode karyawisata belum dapat meningkatkan minat belajar siswa. Hal ini dilihat dari angket minat belajar siswa yang terjadi sedikit mengalami peningkatan minat belajar, yakni jumlah siswa yang belum berminat dalam belajar yakni mengalami penurunan.

Berdasarkan jumlah peryataan dan skor yang ditentukan, maka skor maksimal yang akan dicapai siswa yaitu 150 dan skor minimal yaitu 30. Pengukuran minat secara klasikal didasarkan pada rata-rata skor yang diperoleh siswa, kemudian diambil kesimpulan sesuai kriteria dengan rumus yang sudah ditentukan. Hasil rangkuman pengisian lembar angket minat belajar siswa dapat dilihat pada tabel berikut ini.

Siklus I dikatakan belum selesai dalam penerapan metode karyawisata dapat dilihat dari hasil angket siswa yang belum memenuhi indikator keberhasilan. Kelemahan-kelemahan yang ditemui peneliti pada siklus I sebagai berikut:

a) Kegiatan belajar yang kurang kondusif seperti masih banyak siswa yang berbicara dengan teman, baik saat guru menjelaskan materi dan ketika sedang mengerjakan tugas yang diberikan pada sat siklus I.

b) Pelaksanaan pembelajaran karyawisata pada siklus I ini belum dapat meningkatkan semangat belajar siswa dalam mata pembelajaran IPS Terpadu.

c) Rendahnya persiapan dalam melakukan metode karyawisata pada siklus I sehingga minat belajar siswa juga kurang mengalami peningkatan dan siswa juga kurang memahami materi tentang penegertian dan jenis lembaga sosial. 
Historia: Jurnal Program Studi Pendidikan Sejarah

Vol. 3 No. 2 (2018): 77-91

P-ISSN 2301-8305

E- ISSN 2599-0063

\section{Siklus II}

\section{Perencanaan tindakan II}

Pada dasarnya secara teknis pelaksanaan pembelajaran pada Siklus II hampir sama dengan Siklus I, namun lebih memperhatikan hasil refleksi yang diperoleh pada siklus I dan menerapkan metode Karyawisata dengan optimal. Rencana pelaksanaan tindakan dilakukan pada hari Senin 30 Mei 2016. Pembelajaran akan dilaksanakan dengan metode Karyawisata.

Metode Karyawisata yang diterapkan sebelumnya belum optimal, terutama berkaitan dengan informasi yang diperlukan pada saat awal pembelajaran. Pada proses pembelajaran sebelumnya (Siklus I) siswa kurang terlibat aktif dan waktu yang terbatas, sehingga siswa kurang paham apa yang dipelajari dan diperankan dalam metode karyawisata.

\section{Pelaksanaan tindakan II}

Pelaksanaan tindakan yang direncanakan pada hari 2016 pada pukul 14.00-15.00 WIB penelitian melaksanakan siklus II. Kegiatan awal pembelajaran di mulai dengan guru Senin 30 Mei ketua kelas untuk memimpin doa sebelum pembelajaran dimulai, kemudian guru memeriksa kebersihan kelas dan mengabsen siswa, selanjutnya guru menanyakan kabar siswa dan kesiapan siswa dalam mengikuti proses pembelajaran dengan metode Karyawisata. Dalam pengamatan peneliti siswa sudah terlihat lebih tertib dari pada Siklus I. Guru juga tidak lupa memberikan motivasi kepada siswa, agar siswa dapat semangat mengikuti proses pembelajaran IPS Terpadu. Selanjutnya guru menyampaikan tujuan kompetensi dan menyampaikan jenis penelitian yang akan digunakan, seperti angket minat belajar minat belajar siswa pada tiap siklusnya.

Selama proses pembelajaran dengan metode Karyawisata berlangsung siswa terlihat lebih fokus dan bersemangat dikarenakan di dalam tempat karyawisata siswa lebih tertib. Hal ini dikarenakan persiapan yang dilakukan secara matang, yang dimaksudkan untuk mendorong siswa berpikir dalam menyelesaikan masalah yang sedang dilakukan. Guru membimbing siswa memecahkan masalah dan memahami penegertian dan jenis lembaga sosial. 
Historia: Jurnal Program Studi Pendidikan Sejarah

Vol. 3 No. 2 (2018): 77-91

P-ISSN 2301-8305

E- ISSN 2599-0063

\section{Tahap pengamatan Siklus II}

Tahapan pengamatan Siklus II dilakukan untuk mengetahui setiap kegiatan dalam pelaksanaan dengan mengunakan metode Karyawisata. Tahap pengamatan dilakukan bersamaan dengan pelaksanaan tindakan. Selama tahap pengamatan berlangsung guru juga memantau keterampilan sosial siswa dan membimbing siswa dalam mencari solusi dari permasalahan yang diberikan guru. Pada tahap pengamatan ini guru mitra juga mengamati seluruh kegiatan guru bidang studi (peneliti) selama proses pembelajaran. Pada pengamatan siklus kedua, yaitu pengamatan yang dilakukan aktivitas guru dan siswa.

\section{Refleksi II}

Berdasarkan hasil pengamatan yang dilakukan pada siklus II dapat dilihat bahwa penerapan metode karyawisata dapat mmeningkatkan keterampilan sosial siswa dan minat belajar siswa. Hal ini dilihat dari hasil angket siswa yang menunjukan adanya peningkatan minat belajar siswa setelah diterapkan metode karyawisata, tindakan siklus I, tindakan siklus II. Peneliti menyimpulkan bahwa pembelajaran sudah sesuai dengan scenario yang direncanakan dengan menggunakan metode karyawisata menjadikan proses pembelajaran berlangsung dengan suasana menarik dan minat belajar siswa meningkat dengan signifikan karena menghasilkan peresentase yang lebih tinggi. Selanjutnya jika digambarkan dalam grafik persentase minat belajar siswa pada siklus II dapat dilihat sebagai berikut.

\section{Pada Siklus II}

Tabel dan grafik di atas menunjukkan bahwa jumlah siswa yang belum berminat dalam belajar mengalami penurunan dari sebelumnya 25,67\% menjadi 18,033\%. Sedangkan siswa yang mencapai berminat dalam belajar meningkat dari sebelumnya 74,933\% menjadi 81,967\%. Dengan demikian, minat belajar siswa sudah seperti yang diharapkan dengan kondisi semua siswa mencapai kenaikan dalam minat belajarnya. Oleh karena itu tidak dilakukan siklus selanjutnya karena penelitian tindakan sudah dinyatakan berhasil meningkatkan minat belajar siswa. 


\section{Pembahasan Pra Tindakan}

Hasil yang didapat pada pra tindakan dari perencanaan, pelaksanaan, pengamatan, dan refleksi. Minat belajar siswa masih rendah yaitu 49,95 \% yang berminat dan yang tidak berminat $50,05 \%$. Dengan demikian diperoleh tindakan untuk dapat meningkatkan minat belajar siswa. Tindakan yang dipilih dalam rangka meningkatkan hasil belajar siswa adalah penerapan metode karyawisata.

\section{Pembahasan Siklus I}

Hasil yang didapat pada siklus I dari perencanaan, pelaksanaan, pengamatan, dan refleksi. Minat belajar sudah mengalami peningkatan yaitu 74,933\% dari sebelum melakukan tindakan (pra tindakan) 50,05\%. Beberapa hambatan dalam pelaksanaan pembelajaran metode karyawisata pada siklus I antara lain adalah (a) kurangnya kesiapan siswa dalam proses pembelajaran; (b) suasana kelas yang kurang kondusif seperti masih banyak siswa yang berbicara dengan teman.

\section{Pembahasan Siklus II}

Selanjutnya agar lebih jelas peningkatan minat belajar siswa pra tindakan sampai dengan siklus II, dapat dari dilihat pada grafik berikut:

\section{Minat Belajar Siswa pada Mata Pelajaran IPS Terpadu Kelas VIIC SMP Negeri 50 Batam}

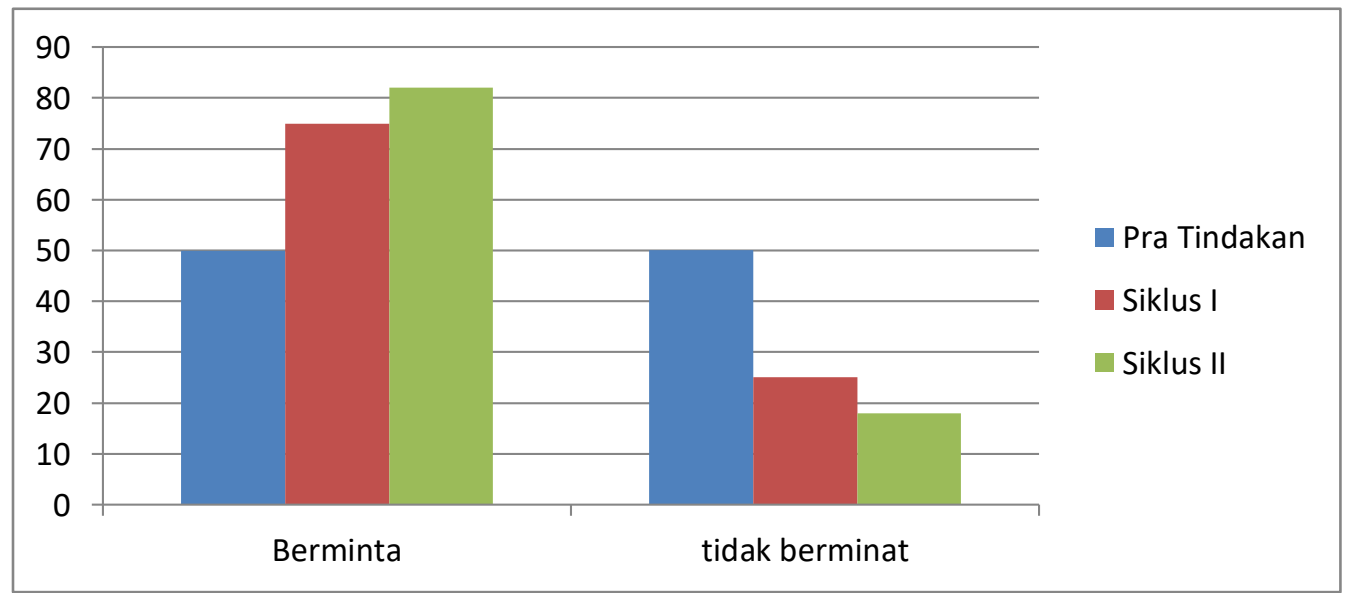

Tabel dan grafik di atas menunjukkan bahwa sebelum pelaksanaan pembelajaran dengan menerapkan metode karyawisata atau pra tindakan, persentase minat belajar siswa sebesar 
Historia: Jurnal Program Studi Pendidikan Sejarah

Vol. 3 No. 2 (2018): 77-91

P-ISSN 2301-8305

E- ISSN 2599-0063

49,95\%. Setelah dilaksanakan pembelajaran dengan menerapkan metode karyawisata terjadi peningkatan persentase minat belajar pada pembelajaran siklus I meningkat menjadi 74,933\% dan pada siklus ke II meningkat menjadi 81,967\%. Dari hasil tersebut dapat diketahui bahwa pada pembelajaran dengan metode karyawisata dapat meningkatkan persentase ketuntasan belajar secara signifikan. Hal ini menunjukkan bahwa pemahaman siswa dalam pembelajaran dengan menggunakan metode karyawisata lebih dapat meningkatkan hasil belajar siswa.

\section{Penerapan Metode Karyawisata untuk Meningkatkan Minat Belajar Siswa}

Hasil yang diperoleh pada pra tindakan sampai siklus II dari perencanaan, pelaksanaan, pengamatan, dan refleksi. Minat belajar sudah semakin menunjukkan peningkatan yang signifikan yaitu $81,967 \%$, dari siklus I 74,933\%, dan pra tindakan 49,95 \%, sedangkan yang tidak berminat mengalami penurunan yaitu pra tindakan 50,05 \%, siklus I $25,067 \%$ dan siklus II $18,033 \%$. Berdasrkan data yang diperoleh peneliti, hasil awal diambil dengan cara memberikan lembar angket sebelum dilakukan metode karyawisata atau pra tindakan sebesar 49,95\% dengan kategori rendah pada mata pelajaran IPS Terpadu, dengan demikian menunjukan minat belajar siswa masih belum optimal. Penerapan metode karyawisata dalam proses pembelajaran IPS Terpadu di kelas VIIC dapat meningkatkan minat belajar siswa. Hal ini terbukti pada siklus II minat belajar siswa meningkat yaitu berkisar $75-100 \%$. Terjadi peningkatan minat belajar dibandingkan dengan sebelum penerapan metode pembelajaran karyawisata atau pra tindakan. Dalam hal ini terjadi peningkatan nilai dibandingkan sebelum penerapan metode karyawisata dalam pembelajaran IPS Terpadu.

Berdasarkan penjelasan tersebut dapat disimpulkan bahwa terdapat peningkatan minat belajar IPS Terpadu. Minat belajar dengan metode karyawisata lebih tinggi dan mampu meningkatkan semangat belajar siswa. Peningkatan tersebut membuktikan dengan metode karyawisata dapat meningkatkan minat belajar siswa. Dengan demikian siswa kelas VIIC SMP Negeri 50 Batam Tahun Pelajaran 2015/2016 yang diberikan pelajaran dengan menggunakan metode karyawisata menghasilkan minat belajar yang lebih baik. 
Historia: Jurnal Program Studi Pendidikan Sejarah

Vol. 3 No. 2 (2018): 77-91

P-ISSN 2301-8305

E- ISSN 2599-0063

\section{KESIMPULAN DAN SARAN}

\section{Kesimpulan}

Berdasarkan hasil penelitian maka dapat diambil kesimpulan bahwa penerapan metode karyawisata dapat meningkatkan minat belajara siswa kelas VIIC SMP Negeri 50 Batam pada proses pembelajaran IPS Terpadu pada materi pokok Pengertian dan jenis lembaga. Adapun kesimpulan secara rinci adalah:

1. Melalui metode karyawisata dapat meningkatkan minat belajar siswa. Hal ini ditunjukkan dengan peningkatan persentase minat belajar siswa dari perencanaan, pelaksanaan, pengamatan, dan refleksi berdasarkan jumlah rata-rata peresentase minat siswa yang diambil dari angket. Pada pra tindakan siswa yang berminat 49,95 \%, siklus I siswa yang berminat sebanyak 74,933\%, sedangkan pada siklus II siswa yang berminat meningkat menjadi $81,967 \%$. Untuk tingkat minat belajar pada penelitian ini sudah dapat dikatakan berhasil karena $\geq 75 \%$ dari jumlah seluruh siswa sudah mencapai kriteria keberhasilan yang ditentukan.

2. Minat belajar siswa melalui metode karyawisata lebih baik dibuktikan dengan melihat hasil angket siswa dari pra tindakan sampai siklus II. Menggunakan metode karyawisata dapat melatih siswa tidak hanya menerima materi pembelajaran saja tetapi siswa juga dilatih untuk berpikir secara kritis dan lebih bersemangat. Metode karyawisata juga dapat meningkatkan imajenasi dan penghayatan siswa.

3. Beberapa hambatan dalam pelaksaan pembelajaran metode karyawisata diantaranya; (a) kurangnya kesiapan siswa dalam proses pembelajaran; (b) suasana yang kurang kondusif seperti masih banyak siswa yang berbicara dengan teman. 
Historia: Jurnal Program Studi Pendidikan Sejarah

Vol. 3 No. 2 (2018): 77-91

P-ISSN 2301-8305

E- ISSN 2599-0063

\section{Saran}

Berdasarkan hasil penelitian yang telah diperoleh maka peneliti mempunyai saran sebagai berikut:

1. Bagi guru

a. Khususnya guru mata pelajaran IPS Terpadu, hendaknya menggunakan metode karyawisata dalam proses pembelajaran agar siswa bersemangat dan tertarik dalam mengikuti pelajaran.

b. Diharapkan untuk berperan aktif dalam meningkatkan pengetahuan dan kompetensi mengajar sehingga kemampuan guru dalam menggunakan variasi metode pembelajaran dapat menjadi lebih baik.

c. Hendaknya selalu mengadakan evaluasi guna mengetahui tingkat penguasaan siswa terhadap materi yang sudah diajarkan.

2. Bagi siswa

a. Siswa hendaknya menumbuhkan kedisplinan dalam mengikuti proses belajar mengajar agar prestasi yang dicapai maksimal. Selain itu pembentukan pengetahuan akan lebih bermakna apabila siswa berpartisipasi aktif didalamnya.

b. Sebaiknya para siswa dapat menyediakan sarana pembelajaran yang lebih lengkap dalam proses pembelajaran sehingga dapat membantu kelancaran proses pembelajaran.

3. Bagi sekolah

Bagi pihak sekolah diharapkan untuk mencipktakan lingkungan belajar dari sarana pembelajaran yang lebih lengkap seperti penambahan buku-buku pelajaran dan lain-lain sehingga dapat membantu kelancaran proses pembelajaran. Selain itu pihak sekolah diharapkan selalu mengikut sertakan para guru dalam pelatihan-pelatihan yang sering dilakukan oleh dinas pendidikan. 
Historia: Jurnal Program Studi Pendidikan Sejarah

Vol. 3 No. 2 (2018): 77-91

P-ISSN 2301-8305

E- ISSN 2599-0063

\section{REFERENSI}

Hamalik, Oemar. 1990. Psikologi Belajar Mengajar. Bandung: Sinar Baru Algensindo.

Hamdayama, Jumanta. 2014. Model dan Metode Pembelajaran Kreatif dan Berkarakter. Jakarta: GI.

Karwati, Euis. 2014. Manajemen Kelas. Jakarta: Alfabeta.

Paizaluddin. 2014. Penelitian Tindakan kelas. Jakarta: Alfabeta.

Rosyada, Dede. 2004. Paradigma Pendidikan Demokratis. Jakarta: Kencana.

Sanjaya, Wina. 2006. Pembelajaran Dalam Implementasi Kurikulum Berbasis Kompetensi. Bandung: Kencana Prenada Media Grup.

Sugiyono. 2010. Metode Penelitian Kuantitatif Kualitatif dan R\&D. Bandung: Alfabeta.

Sutikno, Sobry. 2014. Metode dan Model-model Pembelajaran. Mataram: Holistica.

Susanti, Rini. 2011. Bahan Ajar Belajar dan Pengajaran. Batam.

\section{Penelitian:}

Azlia, Nur. 2015. "Upaya Meningkatkan Aktivitas Belajar Siswa dalam Mata Pelajaran IPS Terpadu dengan Menggunakan Metode Cooperative Learning Tipe Learning Together pada Siswa Kelas VII SMP Negeri 2 Batam Tahun Pelajaran 2014/2015”. Skripsi. Tidak Diterbitkan. Batam: Universitas Riau Kepulauan.

Dinata Poridian Edmon. 2014. "Upaya Peningkatan Hasil Belajar IPS Melalui Model Pembelajaran Kontruktivistik dengan Media Amplok di Kelas VII SMPN 44 Batam T.A.2014/2015”. Skripsi. Tidak Diterbitkan. Batam: Universitas Riau Kepulauan.

Endahwati, Sri. 2010. "Upaya Meningkatkan Minat Belajar Siswa dalam Mata Pelajaran IPS melalui Pembelajaran Contekstual Teaching Learning (CTL) Kelas VII SMP Negeri 9 Batam Tahun Pelajaran 2009/2010". Skripsi. Tidak Diterbitkan. Batam: Universitas Riau Kepulauan.

Gultom, Nurmala. (2012). "Peranan guru IPS dalam Membangkitkan Minat Belajar Siswa Pada Mata Pelajaran IPS di SMP Negeri 12". Skripsi. Tidak Diterbitkan. Batam: Universitas Riau Kepulauan.

Peratiwi, Ratna. 2013. "Peningkatan Minat dan Hasil Belajar Siswa pada Materi Pecahan melalui Model Problem Based Learning di Kelas V Sekolah Dasar Negeri Randugunting 4 Kota Tegal”. Skripsi. Tidak Diterbitkan. Semarang: Universitas Negeri Semarang. 
Historia: Jurnal Program Studi Pendidikan Sejarah

Vol. 3 No. 2 (2018): 77-91

P-ISSN 2301-8305

E- ISSN 2599-0063

Rofikoh, Sri. 2015. "Hubungan Fungsi Perpustakaan dengan Minat Belajar Ilmu Pengetahuan Alam Siswa Kelas VII SMP Negeri 43 Batam Tahun Pelajaran 2014/2015". Skripsi. Tidak Diterbitkan. Batam: Universitas Riau Kepulauan. 